\title{
Distribution of ascidians Phallusia nigra (Tunicata: Ascidiacea) on the north coast of the Persian Gulf, Iran - RETRACTION
}

\author{
MAJID AFKHAMI, MARYAM EHSANPOUR, FARIDA FOROUZAN, KAZEM DARVISH BASTAMI,
} AMIR HOUSHANG BAHRI AND ABDURASOUL DARYAEI

(First published online 27 September 2012)

doi:10.1017/S1755267212000772, Published online by Cambridge University Press, 27 September 2012.

The manuscript "Distribution of Ascidians Phallusia nigra Savigny, 1816 (Tunicata: Ascidiacea) In the North Coast of the Persian Gulf, Iran" was submitted to the journal on 5 June 2012 and following peer review was published online on 27 September 2012. Recently, it has been brought to our attention that significant text (including literature citations) in the paper was previously published by other authors. These issues have not been addressed by the authors through corrigenda. Thus, we have decided to retract the paper.

REFERENCE

Afkhami M., Ehsanpour M., Forouzan F., Bastami K.D., Bahri A.H., and Daryaei A. (2012) Distribution of ascidians Phallusia nigra (Tunicata: Ascidiacea) on the north coast of the Persian Gulf, Iran. Marine Biodiversity Records 5. 